\title{
Silence is the Language of God and Source of Strength: Exploring the Hidden Benefits of Silence
}

\author{
Alim A* \\ Department of Law, University of Rajshahi, Bangladesh
}

*Corresponding author: Abdul Alim, Professor Department of Law, University of Rajshahi, 6205, Bangladesh, Tel: 88-01714896132; Email: alimlaw05@gmail.com

\section{Research Article}

Volume 4 Issue 2

Received Date: May 24, 2021

Published Date: June 23, 2021

DOI: $10.23880 /$ abca-16000185

\section{Abstract}

Silent is a beautiful powerful boost of positive energy and it is an important aspect of worship. Our mind is moving towards past and future. Bringing mindfulness into the present time during our materialistic society of hectic lives silent evolved as a relief mode for relaxation and happiness. World Health Organization and the European Commission's Joint Research Centre concluded that a steady dose of noise pollution could lead to higher blood pressure and fatal heart attacks. It was the result of the research found that high rates of cholesterol and hypertension in individuals regularly exposed to loud noises at work. In this situation silence can actually stimulate new cell growth in the brain, improve memory, and release tension in the brain and body. In fact, two minutes of silence is more effective in relieving physical tension than listening to relaxing music.

Keywords: Silence; God's Language; Benefits; Strength

\section{Introduction}

\section{Prelude}

Silence is an ocean. Speech is a river. Silence is the language of God [1]. To the Sherlock Holmes observation, in a silent mode dog's failure to bark during the night was significant and suspicious [2]. There are some people is in the world who dislike a silent environment comparing it being alone and lonely. Many of us aren't aware of the profound benefits of silence mode. This silence practice increases awareness, concentration, and creativity. Establishing this virtue manages power over the mind and body which results in a positive attitude. When peoples' inner world changes so does the outer world. The Mahabharata, the Vedas, and the Upanishads all state that by immersing in deep silence, one can get in touch with one's own soul. In Christianity, Saint Pio of Pietrelcina, who said: "Through the study of books one seeks God; by meditation one finds him." After the day's work, Jesus urged the people to pass some time in selfreflection, identify their mistakes, and change their lives in the light of that reflection. The famous encounter of Moses with God happened after he had spent 40 days meditating in the Sinai mountains.

\section{Silence: Physical Health and Well-being}

The ancient people in the Indian Sub-continent were practice keeping silent mode which was thought of as a supernatural or extraordinary process through which one can enjoy the mental, physical, social and spiritual benefits. Now a day it is fixed only for hermits or monks to practice. Under the leadership of Dr. Clifford Saron of the University of California's 'Center for Mind and Brain', a group of a scientist conducting three months of research and shows one doesn't have to be a monk or an expert to enjoy silence benefits 
"Training allows us to transform the mind, to overcome destructive emotions and to dispel suffering," says Buddhist monk Matthieu Ricard [3]. "The numerous and profound methods that Buddhism has developed over the centuries can be used and incorporated by anyone. What is needed is enthusiasm and perseverance" [4].

Scientifically, silence has been shown to offer significant health advantages that boost overall well-being. From a physiological standpoint, silence helps:

- Lower blood pressure, which can help prevent heart attack.

- Overcoming insomnia and developing healthy sleeping habits.

- Boost the body's immune system.

- Benefit brain chemistry by growing new cells [5].

- Having the realization in mind that trust and hope create new chances and confusion and frustration gets failure.

- Decrease stress by lowering blood cholesterol levels and adrenaline.

- Promote good hormone regulation and the interaction of bodily hormone-relate systems [6].

A 2013 study on mice published in the journal Brain, Structure and Function used different type of noise and silence and monitored the effect the sound and silence had on the brains of the mice [7]. The silence was intended to be the control in the study but what they found was surprising. The scientists discovered that when the mice were exposed to two hours of silence per day they developed new cells in the hippocampus. The hippocampus is a region of the brain associated with memory, emotion, and learning.

\section{Silence: Psychological and Emotional Benefits}

It is known that the subconscious mind is very active and creative during rest or sleep. Taking a break from difficulties at home, work, or school is often best accomplished with a conscious choice to entertain silence. Without the distractions of tech devices, ringing phones, incoming messages, unexpected assignments, or the demands of children, co-workers, family members, and friends, it's easier to calm the mind and restore balance. It can connect with your inner true self, your field of pure potentialities, and feeling the form of soul.

Silence may help in the following areas:

Improves Attention: The Journal of Neuroscience proves silence improves concentration and attention had been proven by a group of researchers at the University of Wisconsin-Madison.

Creativity: When allowing thoughts to go where they will, inspiration may bubble up. Solutions to current or longstanding problems may suddenly occur to you, or a workaround or innovative approach may seem more feasible.
Ideas for going in a different path could coalesce, helping build momentum and excitement for spinning them off into yet other potential avenues to pursue.

Reduces Emotional Reaction: Silence has a profound effect on feelings and emotions. When the task was very monotonous, boring and then the University of West Virginia, researchers found that it can help gain more control over emotions by helping regulate the activities of the brain's amygdala. In another study conducted Dr. Baljinder Sahdra, stated, "As we have seen, due to meditation the volunteers have a reduced tendency to be tense, and are better able to control their negative emotions. Meditation reduces a person's emotional reactivity which is the tendency to react very emotionally."

Awareness of Self and Environment: Once you're comfortable in your silence, you'll notice a distinct shift in your ability to be more self-aware. In 2009, the Centre for Compassion and Altruism Research and Education was created at Stanford University. The Centre's aim is to research and understand the neurobiological links behind human emotions such as compassion, affection and sympathy. The Center's roster includes neuroscientists, big corporate investors of Silicon Valley, and even Dalai Lama. They all have one goal; which is to comprehend how meditation creates all these emotions in a human being. After those researches mental training gymnasiums were introduced. These gyms work like normal gyms, but instead of strong muscles these gyms help you build strong, positive, and beneficial emotions.

\section{Suggestions for Entertaining Silence}

You might think, and anyone can begin to cultivate silence to help benefit the overall health and well-being of a circle of a healthier lifestyle. After meditating in silence, you may be more motivated to mend significant relationships that have become strained, embark upon a self-improvement program. Then try these suggestions:

- You can also walk solo to get more in tune with nature and fresh air and allow your mind to take a quiet timeout.

- Before going to bed or getting up say a silent prayer of gratitude for all that you have and ask for blessings for the day ahead.

- Try to engage in deep breathing exercises. This helps calm your mind and quiet it at the same time.

- Try to meditate by yourself at home and one can just download the Relaxation meditations and start practicing.

\section{Conclusion}

To get inner peace Muslims are instructed in their everyday life and experience making daily space for silence. The Prophet Muhammad encouraged and said, "Whoever 


\section{Annals of Bioethics \& Clinical Applications}

believes in God and the Last Day should speak a good word or remain silent." If we want to focus our attention then mute the noise and learn the art of silence. It is an art of powerful communication to solve the problematic situations. The famous psychologist and philosopher William James said, "The greatest discovery of any generation is that a human can alter his life by altering his attitude. According to World Health Organization, health is a state of complete physical, mental, social and spiritual well-being and not merely the absence of disease or infirmity. So, we need to meditate in our everyday life like medicine and nutritious food for good health. Inner peace is important and that can be attained by having the right attitude with silent mode. Spiritually human beings are born with the intrinsic urge to worship, to pray, to surrender them to a higher being. Following this silent philosophy the modern people of the new millennium, could help fulfill their potential, enrich their lives so that it brims over with peace and prosperity.

\section{References}

1. Muhammad Rumi JD (1207) was a 13th-century Persian Muslim poet, jurist, theologian, and Sufi mystic.

2. Blaze SD (1894) In the Memoirs of Sherlock Holmes (investigating the disappearance of a race horse, Holmes deduces from the watchdog's failure to bark that the horse was taken by his trainer with whom the dog was familiar).

3. Matthieu Ricard was called the "happiest man in the world," is a Buddhist monk, author and photographer. He has been the subject of intensive clinical tests at the University of Wisconsin.

4. Bond M (2011) Mind gym: Putting meditation to the test, NewScientist.

5. (2013) A study found that two hours of silence could create new cells in the hippocampus region, a brain area linked to learning, remembering, and emotions.

6. (2006) According to a study in Heart, two minutes of silence relieves tension in the body and brain and is more relaxing than listening to music. This was attributed to changes in blood pressure and blood circulation in the brain.

7. Gellért L (2013) "Astrocytic and neuronal localization of kynurenine-aminotransferase II in the adult mouse brain" in Brain Structure and Function 218(4). 